\title{
Evaluation of eight maize genotypes for yield and yield contributing traits
}

\author{
Shafiullah ${ }^{1}$, Rashid Jalal ${ }^{*}$, Abdul Basir ${ }^{2}$, Jan E Alam ${ }^{3}$, Arshad Ali ${ }^{3}$, Gul \\ Roz Khan ${ }^{1}$, Abdul Aziz ${ }^{1}$, Muhammad Mehran Anjum ${ }^{1}$, Sunila ${ }^{4}$ and \\ Imad $\mathrm{Khan}^{3}$ \\ 1. Department of Agronomy, The University of Agriculture Peshawar-Pakistan \\ 2. Department of Agronomy, The University of Swabi-Pakistan \\ 3. Department of Agronomy, The University of Agriculture Peshawar, Amir Muhammad Khan Campus Mardan- \\ Pakistan \\ 4. Department of Food Science and Technology, The University of Agriculture Peshawar-Pakistan \\ *Corresponding author's email: rashidjalal@aup.edu.pk
}

Citation

Shafiullah, Rashid Jalal, Abdul Basir, Jan E Alam, Arshad Ali, Gul Roz Khan, Abdul Aziz, Muhammad Mehran Anjum, Sunila and Imad Khan. Evaluation of eight maize genotypes for yield and yield contributing traits. Pure and Applied Biology. Vol. 7, Issue 2, pp620-624. http://dx.doi.org/10.19045/bspab.2018.70077

\begin{tabular}{llll}
\hline \hline Received: 22/02/2018 & Revised: 30/04/2018 & Accepted: 02/05/2018 & Online First: 12/05/2018 \\
\hline
\end{tabular}

\section{Abstract}

Changing climatic scenario arise the problem of varietal adaptation. A field trail was conducted to evaluate eight different genotypes at Agricultural research Institute (ARI) Tarnab, Khyber Pakhtunkhwa, Pakistan during summer 2015-16. Maize genotypes Azam, Iqbal, 8003-4*66211, Babar, Pop-2009, Jalal, Pahari, and Sarhad White were tested in randomized complete block design replicated three times. Results of the trail showed that plant-height $(\mathrm{cm})$, ear plant ${ }^{-1}$, single ear weight, 1000-grain weight, grain yield, biological yield and harvest index were higher with maize genotype $80003-4 * 66211$, while ASI was recorded similar for all genotypes. Thus it is suggested that the genotypes $80003-4 * 66211$ may be preferred for general cultivation under existing environmental conditions.

Keywords: Grain yield; Maize; Plant height; Replications; Varieties

\section{Introduction}

Sustained agriculture development in Pakistan is a pre-request to cope with the demand of increasing population. Increase in yield on sustainable basis requires implementation of agricultural practices based on scientific evaluation. Maize (Zea mays L.) is the most important cereal crop after wheat and rice in Pakistan. Maize plant is tall with hollow stem and the leaves are arranged alternatively on stem. Its leaf consist of leaf sheath grasp the stem and long narrow leaf blade. Maize crop require subtropical climate but also grown in tropical and temperate zone of the world because of its adoptability to environmental condition. In Pakistan the total production of maize is 4.53 million tons from an area of 1.12 million ha [1]. In Pakistan average grain yield of maize is very low as compared to the developed countries of the world e.g. USA, Russia, Brazil and China. In 2011-12 cereal crop occupied total area $79.34 \%$ in which maize covered $17 \%$ with an average yield of $2.95 \mathrm{t} \mathrm{ha}^{-1}$ [2], while the world's averages yield of the maize crops is about $5.21 \mathrm{t} \mathrm{ha}^{-1}$ [3]. The low productivity of maize because of poor seed quality, lack of technologies, low 
soil fertility, imbalance nutrient, poor practices, low input use, disease attack, insect and pest and also weeds [4]. The changing climatic condition had adverse effect on Pakistan agriculture system, so in Pakistan the major problem is the adoptability of maize verities. A genetically superior genotype with good management practices can increase crop yield and thus ultimately economic return of farmer is more as compare to conventional agriculture system. The yield can be increased while using suitable maize variety adoptable to the climatic condition of the area with good management practices. Low yield of maize is due to the variability in genetic potential and unstable cultivars [5]. The maize verities have significant effect on the growth and growth parameters contributing to the final yield [6]. Maize varieties significantly differ in nutrient uptake, competition with weeds and utilizing of solar radiation. Maize genotypes with dense canopy production and position of leaves on the stem had great impact on solar radiation utilization, and thus assimilate production is altered. Maize varieties and their adaptation in different agro-ecological zones, yield potential and reaction of diseases so as to do bitter adaptation to adverse environmental condition [7].

Keeping in view the importance of maize genotypes in improving maize production in the country, the experiment was conceptualized to find out suitable maize genotypes adoptable to the climatic condition of the study area.

\section{Materials and methods}

A trail aimed on "evaluation of maize genotypes for yield and yield contributing traits" was conducted in Agricultural Research Institute (ARI) Taranab, Khyber Pakhtunkhwa, Pakistan during summer 201516. The field was ploughed with cultivator followed by rotavator for a uniform seedbed preparation. Maize genotypes Azam, Iqbal,
8003-4*66211, Babar, Pahari, Pop-2009, Jalal, and Sarhad White were sown at a seed rate of $30 \mathrm{~kg} \mathrm{ha}^{-1}$ in Randomized complete block design using three replications. The plot size was $3.5 \mathrm{~m}$ x $5 \mathrm{~m}$ consisting of six rows $5 \mathrm{~m}$ long and $70 \mathrm{~cm}$ apart. Plant to plant distance was maintained at $20 \mathrm{~cm}$. The crop was irrigated according to needs and environmental condition. All the agronomic practices were applied uniformly in each experimental unit.

Collected data were analyzed using analysis of variance appropriate for randomized complete block design. Least significant difference (LSD) test at 5\% level of probability were perform after getting significant variations among genotypes.

\section{Results and discussion Plant height (cm)}

Plant height of maize were significantly $(p \leq 0.05)$ different for maize genotypes (Table 1). Maximum plant height (166.33 $\mathrm{cm})$ was observed for $80003-4 * 66211$ that was statistically at par with Sarhad white. Plant height of maize verity Azam was $(161.67 \mathrm{~cm})$ that were statistically similar to pahari $(156.33 \mathrm{~cm})$. Genotype Baber resulted in shorter plants as compare to other genotypes. The variation in plant height would be elaborate by the fact that this might be the genetic property of genotypes. Our results authenticate the findings of [8] reported variation among genotypes for plant height of maize.

\section{Anthesis-silking interval (ASI)}

Result regarding response of ASI of different maize genotypes is furnished in (Table 1). Statistical analysis of the data revealed that ASI is not significantly $(p \leq 0.05)$ affected by maize genotypes. This might be due to the resemblance in genetical characteristic of maize genotypes.

\section{Ear plant $^{-1}$}

Analysis of the data in (Table 1) revealed that ear plant ${ }^{-1}$ is considerably $(\mathrm{p} \leq 0.05)$ different for maize genotypes. Variety 80003-4*66211 
produce maximum ear plant ${ }^{-1}$ (1.03) followed by Pop-2009. Ear plant ${ }^{-1}$ of variety iqbal (0.73) that was statistically similar to Sarhad white (0.73) and Azam (0.70). However Jalal and Baber genotypes produce minimum number of ear plant $^{-1}(0.60)$. Maximum ear plant $^{-1}$ possibly due to efficient utilization of available resources like nutrients, water and solar radiation to maximize reproductive growth.

\section{Single ear weight (g)}

Single ear weight (g) of maize is considerably varied among various genotypes (Table 1). Heavier ear (144.57 g) was observed in genotype $80003-4 * 66211$ which is followed by Jalal $(115.33 \mathrm{~g})$ that were statistically different to Iqbal (59.83 g). While lighter ears $(59.83 \mathrm{~g})$ were found for Iqbal. Ear weight is different for maize genotypes, and this could be due to higher assimilate production and translocation capacity of a genotype towards ear. Similar results were also reported by [9] found differences in ear weight for various maize genotypes.

Table 1. Plant height, anthesis-siliking interval, ear plant ${ }^{-1}$, and ear weight of different maize genotypes

\begin{tabular}{|c|c|c|c|c|}
\hline Treatments & $\begin{array}{c}\text { Plant height } \\
(\mathbf{c m})\end{array}$ & ASI & Ear plant $^{-1}$ & Ear weight (g) \\
\hline $80003-4 * 66211$ & $166.33 \mathrm{a}$ & 4.00 & $1.0333 \mathrm{a}$ & $144.57 \mathrm{a}$ \\
\hline Babar & $146.33 \mathrm{~b}$ & 3.0 & $0.60 \mathrm{~b}$ & $117.50 \mathrm{abc}$ \\
\hline Azam & $161.67 \mathrm{ab}$ & 3.33 & $0.70 \mathrm{ab}$ & $107.43 \mathrm{bcd}$ \\
\hline Iqbal & $147.67 \mathrm{ab}$ & 3.33 & $0.7333 \mathrm{ab}$ & $59.83 \mathrm{e}$ \\
\hline Jalal & $154.0 \mathrm{ab}$ & 4.33 & $0.60 \mathrm{~b}$ & $115.33 \mathrm{abc}$ \\
\hline Pahari & $156.33 \mathrm{ab}$ & 4.33 & $0.70 \mathrm{ab}$ & $81.40 \mathrm{de}$ \\
\hline Sarhad white & $164.33 \mathrm{ab}$ & $3.33 \mathrm{bc}$ & $0.7333 \mathrm{ab}$ & $89.93 \mathrm{cde}$ \\
\hline Pop-2009 & $157 \mathrm{abc}$ & 5.0 & $1.00 \mathrm{ab}$ & $127.67 \mathrm{ab}$ \\
\hline LSD $(0.05)$ & 15.78 & Ns & 0.4309 & 31.935 \\
\hline
\end{tabular}

\section{Thousand grain weight (g)}

Data in (Table 2) revealed that thousand grain weight $(g)$ is statistically different $(\mathrm{p} \leq 0.05)$ for maize genotypes. Maximum thousand grain weight (188.4 g) was found for 800034*66211 followed by Sarhad white, while the rest of the genotypes are similar in term of grain weight. This variation is due the nonresemblance in duration of grains filling stage which alter the final grains weight of maize genotypes. Our results are in line with [10] reported variation in thousand grain weight with various genotypes.

\section{Biological yield ( $\left.\mathrm{kg} \mathrm{ha}^{-1}\right)$}

Biological yield of maize is considerably varied for maize genotypes (Table 2). Maximum biological yield (7179.8 $\left.\mathrm{kg} \mathrm{ha}^{-1}\right)$ was produced by $80003-4 * 66211$. Pahari genotype of maize produce minimum biological yield $\left(6558.3 \mathrm{~kg} \mathrm{ha}{ }^{-1}\right)$. The differences in biomass production is due to different assimilates accumulation rates and the ability of a genotype to utilize the available resources efficiently. Our results authenticate the finding of [11] experienced that jalal variety produce maximum biological yield.

Grain yield (kg ha-1)

Grain yield is significantly $(\mathrm{p} \leq 0.05)$ varied among different maize genotypes (Table 2). ANOVA results revealed that maize genotypes perform different in term of grain yield production. Genotype80003-4*66211 produce maximum yield (3040 kg ha-1) which is statistically similar to sarhad white, while Iqbal produce minimum yield (1477.7 $\left.\mathrm{kg} \mathrm{ha}^{-1}\right)$. The final grain yield is significantly affected by various genotypes. Higher grain 
number and weight is due to efficient utilization of solar radiation, maximum assimilates production and its conversion to starch resulted more grain and biomass production [11]. Similarly, [12] identified maize genotypes performing well among tested genotypes in term of grain yield.

Harvest index (\%)

Data regarding harvest index is furnished in table 2. ANOVA results of the data revealed that $\mathrm{HI}$ is considerably different for maize genotypes. Genotype $80003-4 * 66211$ results in higher HI (42.3\%) followed by Sarhad white. This increase in harvest index is due to increase in grain yield and biological yield. In term of harvest index significant variation were observed in maize genotypes. Our results are in conformation with [10] find different harvest index with different genotypes.

Table 2. Thousand grain weight, biological yield, grain yield and harvest index of different maize genotypes

\begin{tabular}{|c|c|c|c|c|}
\hline Treatments & $\begin{array}{c}\text { Thousand grain } \\
\text { weight } \mathbf{( g )}\end{array}$ & $\begin{array}{c}\text { Biological yield } \\
\left(\mathbf{k g ~ h a}^{-1} \mathbf{)}\right.\end{array}$ & $\begin{array}{c}\text { Grain yield (kg } \\
\mathbf{h a}^{-\mathbf{1}} \mathbf{)}\end{array}$ & $\begin{array}{c}\text { Harvest index } \\
(\mathbf{\%})\end{array}$ \\
\hline $80003-4 * 66211$ & $188.4 \mathrm{a}$ & $7179.8 \mathrm{a}$ & $3040 \mathrm{a}$ & $42.3 \mathrm{a}$ \\
\hline Babar & $160.0 \mathrm{c}$ & $6748.3 \mathrm{bc}$ & $1820.3 \mathrm{bc}$ & $26.9 \mathrm{bc}$ \\
\hline Azam & $159.9 \mathrm{c}$ & $6574.7 \mathrm{c}$ & $2178 \mathrm{bc}$ & $33.17 \mathrm{ab}$ \\
\hline Iqbal & $160.3 \mathrm{c}$ & $6824.7 \mathrm{abc}$ & $1477.7 \mathrm{c}$ & $21.67 \mathrm{c}$ \\
\hline Jalal & $160.3 \mathrm{c}$ & $6747.3 \mathrm{bc}$ & $2146.7 \mathrm{bc}$ & $31.6 \mathrm{abc}$ \\
\hline Pahari & $160.2 \mathrm{c}$ & $6558.3 \mathrm{c}$ & $2178 \mathrm{bc}$ & $33.3 \mathrm{ab}$ \\
\hline Sarhad white & $172.7 \mathrm{~b}$ & $7113.3 \mathrm{ab}$ & $3002 \mathrm{a}$ & $42.26 \mathrm{a}$ \\
\hline Pop-2009 & $160.6 \mathrm{c}$ & $6917.3 \mathrm{abc}$ & $2591 \mathrm{ab}$ & $37.34 \mathrm{ab}$ \\
\hline LSD $(0.05)$ & $\mathrm{Ns}$ & 377.59 & 819.70 & 11.228 \\
\hline
\end{tabular}

Means followed by different latters in each column are significantly different from each other at $5 \%$ level of significance

\section{Conclusions and recommendations}

From the results it is concluded that genotype $80003-4 * 66211$ perform well as compare to other test genotypes. So, it is suggested that this genotype is adoptable to the existing climatic condition of the study area, so the genotype $80003-4 * 66211$ is recommended for general cultivation in study area.

\section{Authors' contributions}

Conceived and designed the experiments: $\mathrm{R}$ Jalal \& A Baser, Performed the experiments: R Jalal, A Aziz \& Shafiullah Analyzed the data: A Ali, Shafullah \& GR Khan, Contributed reagents/ materials/ analysis tools: MM Anjum, Sunila \& I Khan, Wrote the paper: Shafiullah, JE Alam \& A Ali.

\section{References}

1. MNFS\&R (2013-14). Ministry of National Food Security and Res, Eco,
Wing, Govt. of Pak, Islamabad.

2. CSA (Central Statistical Agency) (2012). Area and production of major crops. Agricultural sample survey 201213, private, peasant holdings, Meher season, Statistical Bulletin 532, Addis Ababa, Ethiopia.

3. FAO (Food and Agriculture organization of the United Nations) (2011). FAOSTAT online database, available at link http://faostat.fao.org/. Accessed on December 2013.

4. CIMMYT (International Maize and Wheat Improvement Center) (2004). Second Semi-Annual Progress Report for the Quality Protein Maize Development Project for the Horn and East Africa (XP 31519).

5. Tahir M, Tanveer A, Ali A, Abbas M \& 
Wasaya A (2008). Comparative yield performance of different maize (Zea mays L.) hybrids under local conditions of Faisalabad-Pakistan. Pak J Life Soc Sci 6(2): 118-120.

6. Olakojo SA \& Iken J (2001). Yield performance and stability of some improved maize varieties. Moor J Agric 2: 21-24.

7. Trethowan RM, Crossa J, Ginkel M \& Rajaram S (2001). Relationships among bread wheat international yield testing locations in dry areas. Crop Sci 41: 1461-1466.

8. Abbas G, Hussain A, Ahmad A \& Wajid SA (2005). Effect of Irrigation Schedules and nitrogen rates on yield and yield components of Maize. J of Agri and Soc Sci 1: 335-338.

9. Hussain N, Khan MY \& Baloch MS
(2011). Screening of maize varieties for grain yield at Dera ismail khan. J of Anim \& Plant Sci 21(3): 626-628.

10. Akmal M, Rehman HU, Farhatullah, Asim M \& Akbar H (2010). Response of maize varieties to nitrogen application for leaf area profile, crop growth, yield and yield components. Pak J Bot 42(3): 19411947.

11. Derby NE, Casey FXM, Knighton RE \& Steel DD (2004). Midseason nitrogen fertility management for corn based on weather and yield prediction. Agron J 96: 494-501.

12. Kandil EEE (2013). Response of Some Maize Hybrids (Zea mays L.) to Different Levels of nitrogenous Fertilization. J of Appli Sci Res 9(3): 1902-1908. 